ISSN 1392-3196 / e-ISSN 2335-8947

Zemdirbyste-Agriculture, vol. 103, No. 3 (2016), p. 297-304

DOI 10.13080/z-a.2016.103.038

\title{
Biomass yield and fibre components in reed canary grass and tall fescue grown as feedstock for combustion
}

\author{
Lina POCIENĖ, Žydrė KADŽIULIENĖ \\ Institute of Agriculture, Lithuanian Research Centre for Agriculture and Forestry \\ Instituto 1, Akademija, Kèdainiai distr., Lithuania \\ E-mail: lina.pociene@1zi.lt
}

\begin{abstract}
Grass biomass is a potential feedstock for solid biofuel production. This paper presents the results of experiments conducted on Endocalcari-Epihypogleyic Cambisol (CMg-p-w-can) to evaluate the biomass yield, quality and bioenergy potential of tall fescue (Festuca arundinacea Schreb.) and reed canary grass (Phalaris arundinacea L.). Two kinds of fertilizers mineral nitrogen $\left(90 \mathrm{~kg} \mathrm{ha}^{-1}\right)$ and biogas waste (digestate) with the same amount of nitrogen and one-cut regime either in July or in October were chosen to estimate the biomass productivity and energy potential. The results of a two-year experiment suggest that the biomass yield and energy potential depended on the grass species and cultivation technology. Higher biomass and energy yields were produced by reed canary grass when harvested in July, while by tall fescue when harvested in October. Both grass species were most productive when fertilized with mineral nitrogen. Of the two grass species and harvesting dates tested, the highest biomass and energy yields were produced by reed canary grass swards harvested in July. It was proved that the highest content of lignin in the biomass led to the highest energy yield of swards.
\end{abstract}

Key words: biomass for combustion, grass species, harvesting time, nitrogen fertilization.

\section{Introduction}

Many countries in Europe and other regions are dependent on fossil energy sources. In order to maintain a sufficient amount of energy supplies for future generations and less reliance on imports, there is a necessity to find a proper alternative to fossil fuels. Solar, wind, wave, geothermal as well as biomass energy may contribute to the increase in the use of renewables in the energy sector. In Northern European countries one of the most important sources of renewables are wood biomass and wood residues (Healion, 2002; Doherty et al., 2012). On the other hand, the use of agricultural crops may also contribute to the increase of the use of biomass in energy generation. Energy crops have been reported as potential solid biofuels in Northern Europe (Lewandowski et al., 2003; Wrobel et al., 2008; Panoutsou et al., 2011; Robbins et al., 2012; Allen et al., 2014; Tilvikiene et al., 2016). The competitiveness of an energy crop as combustion fuel is influenced by multiple factors, including fuel properties, energy yield per hectare, seasonal availability and others (Robbins et al., 2012; Butkute et al., 2014). However, these factors influence a number of other interactions such as plant species, specific growing conditions, crop cultivation technology.

Perennial grasses can be selected for bioenergy, because they have some advantages over other plants: it is easier to establish their swards compared to other energy crops as they can be sown from seeds and do not require high costs and thereafter can be dispensed with lower inputs (Jasinskas et al., 2008; Wrobel et al., 2008). Grass has the advantage over straw biomass or other agricultural residues because its harvesting time can be alternated, which prevents from shortage of feedstock. In addition, often attention is drawn to grasses as they can yield in less fertile soils (Lord, 2015; Nilsson et al., 2015). However, considering the choice of perennial grass species as a feedstock, appropriate biomass yield is relevant because it is one of the most important aims for solid biofuels.

One of the most promising cool-season grasses for biofuel is reed canary grass which could produce 4-15 tha $\mathrm{t}^{-1}$ and sometimes more of annual dry matter yield (Jasinskas et al., 2008; Wrobel et al., 2008; Heinsoo et al., 2011; Kallioinen et al., 2012; Kołodziej et al., 2016). Heinsoo et al. (2011) have reported that the highest yield per hectare was obtained late in October and it reached $12.7 \mathrm{t} \mathrm{ha}^{-1}$ of dry matter (DM) on mineral soils in Estonia. In Canada, according to Wrobel et al. (2008), biomass yield topped 15 tons of dry matter per hectare. Tall fescue (Festuca arundinacea Schreb.) has also been reported as one of the grasses suitable for bioenergy in northern climate and its yields could range from 1 to more than $10 \mathrm{t} \mathrm{ha}^{-1}$ (Seppälä et al., 2009; Lemežiené et al., 2011; Tilvikiene et al., 2016). In different soil and climatic conditions the biomass yield of the same grass 
species is different and it is always associated with the growing technology, stages of plant development and their interactions (Jasinskas et al., 2008; Butkute et al., 2014; Kołodziej et al., 2016). The choise of harvesting time is one of the key factors impacting on the quality of grass biomass as feedstock for combustion. Harvesting time could strongly affect not only yield stability but also influence the biomass chemical composition. The perennial grasses harvested at booting stage or full maturity accumulate different amounts of biomass and its composition is different (Kandel et al., 2013; Kołodziej et al., 2016).

Bio energy production from grass biomass is an alternative to fossil fuels. In this case not only biomass yield is important but also chemical composition of herbage biomass which can improve or limit its suitability for combustion process (Han et al., 2013; Vassilev et al., 2013). Fuel quality is determined by the physical and chemical properties and influences the entire process of thermal utilization. High levels of cellulose and hemicellulose are desirable in a biofuel, with the optimal level of hemicellulose depending on the biomass processing used (Wrobel et al., 2008). For solid biofuels a high concentration of lignin is desirable in the biomass (Robins et al., 2012; Rancane et al., 2015) because of its ability to increase the durability of pellets formed from the dried biomass for combustion purposes, besides highly lignified biomass has high content of carbon in lignin which leads to higher heating value (Wrobel et al., 2008; Prochnow et al., 2009).

The objective of the current study was to assess the influence of harvesting time on the yield of biomass as a feedstock for combustion, on the content of fibre components (cellulose, hemicellulose and lignin) and energy yield of perennial energy crops - reed canary grass and tall fescue grown in a northern climate zone.

\section{Materials and methods}

Experimental site. Samples of reed canary (Phalaris arundinacea L.) and tall fescue (Festuca arundinacea Schreb.) grasses were collected from experimental sward plots located at the Institute of Agriculture, Lithuanian Research Centre for Agriculture and Forestry (lat. 55 $40^{\prime} \mathrm{N}, 23^{\circ} 87^{\prime} \mathrm{E}$ ) in 2013 and 2014 years. In our study, we used reed canary grass variety 'Chiefton' and tall fescue variety 'Navas'. The results were obtained over the first and second year of sward use. The soil of the experimental site is an EndocalcariEpihypogleyic Cambisol (CMg-p-w-can) with a loam texture. The experiment was laid out in a randomized complete block design with three replicates. The plot size was $3 \times 10 \mathrm{~m}$. The harvested plot size was $25 \mathrm{~m}^{2}$.

Three levels of nitrogen fertilization were used: $\mathrm{N}_{0}$ - no $\mathrm{N}$ fertilization, $\mathrm{N}_{90 \text { (mineral) }}$ - fertilization with mineral nitrogen $90 \mathrm{~kg} \mathrm{ha}^{-1}$ and $\mathrm{N}_{90(\text { digestate) }}$ - fertilization with biogas production residue at the beginning of the vegetation season. The amount of residue was adjusted to fit nitrogen fertilization level of $90 \mathrm{~kg} \mathrm{ha}{ }^{-1}$. For comparison of harvesting time influence on biomass quantity and quality, two harvesting times were selected. For the first treatment - the first cut at the end of July (the biomass after the first cut in July was harvested for the second time in October, the biomass yield of the second cut was not included in this assessment); for the second treatment - there was one harvesting time in the middle of October. All of the collected biomass samples were weighed on site to measure the moisture content. Then all samples were transported to the lab on the same day and dried for $12 \mathrm{~h}$ at $105^{\circ} \mathrm{C}$, the dry weight was measured. For analysis of biomass chemical composition and calorific value fresh biomass samples were chopped to $3-5 \mathrm{~cm}$ pieces, fixed at $105^{\circ} \mathrm{C}$ for $15 \mathrm{~min}$, and dried $\left(65 \pm 5^{\circ} \mathrm{C}\right)$. Dried samples were ground with a cyclone mill, using a sieve with $1 \mathrm{~mm}$ diameter holes.

The analysis of chemical composition and energy potential. The Van Soest method was used to estimate the fraction of cellular tissue characterised as neutral detergent fibre (NDF), acid detergent fibre (ADF) and acid detergent lignin (ADL). Then they were recalculated to cellulose, hemicellulose and lignin by methodology of Rinne et al. (1997). Heating value was measured with a colorimeter IKA C200 (IKA®-Werke GmbH \& Co. KG, Germany) and expressed in $\mathrm{MJ} \mathrm{kg}^{-1}$ dry matter (DM). The energy yield $\left(\mathrm{GJ} \mathrm{ha}^{-1}\right)$ was calculated:

$\mathrm{Q}=(\mathrm{Hd} \times \mathrm{Qg}) / 1000$, where $\mathrm{Q}$ is energy yield, GJ ha-1 ${ }^{-1} \mathrm{Hd}$ - biomass dry yield, $\mathrm{kg} \mathrm{ha}^{-1}, \mathrm{Qg}$ - calorific value, $\mathrm{MJ} \mathrm{kg}^{-1}$.

Statistical analysis. Statistical differences of annual biomass yield were analysed as a three-factor analysis of variance (ANOVA). Statistical analyses were performed and averages of replicates were calculated. The correlation between energy yield and ADL was estimated.

Table 1. Average monthly air temperature and accumulated precipitation during the vegetation period

\begin{tabular}{cccccccc}
\hline & April & May & June & July & August & September & October \\
\hline \multicolumn{7}{c}{ Air temperature ${ }^{\circ} \mathrm{C}$} \\
\hline 2013 & 4.7 & 16.0 & 18.6 & 18.5 & 18.1 & 12.6 & 8.5 \\
2014 & 8.9 & 13.0 & 14.4 & 20.0 & 17.7 & 13.3 & 7.3 \\
Multiannual average & 6.0 & 12.3 & 15.6 & 17.7 & 16.7 & 12.0 & 6.8 \\
\hline \multicolumn{7}{c}{ Rainfall mm } \\
\hline 2013 & 46 & 49 & 47 & 104 & 42 & 78 & 28 \\
2014 & 27 & 76 & 65 & 69 & 111 & 21,5 & 39 \\
Multiannual average & 37 & 52.3 & 62.5 & 74.2 & 73.7 & 51.3 & 50.1 \\
\hline
\end{tabular}


Meteorological data. The experimental site is characterised by an average annual air temperature of $6.5^{\circ} \mathrm{C}$ and an average annual precipitation of $650 \mathrm{~mm} .2014$ presented higher air temperature and low rainfall level in May and June compared to the multiannual averages.

\section{Results}

Biomass productivity. Biomass productivity is one of the main parameters for crops grown for energy purposes, especially for combustion (Lewandowski et al., 2003; Tanger et al., 2013).

Our study showed that in the first year of sward use biomass yield was significantly affected only by the type of nitrogen fertilizers. In the second year of sward use grass species, nitrogen fertilization, timing of cut as well as interaction between grass species and timing of cut, nitrogen application and timing of cut, and interaction between all the evaluated factors significantly influenced the biomass productivity of perennial grasses.

Reed canary grass produced higher yield than tall fescue in almost all the cases, except in the swards fertilized with mineral nitrogen or digestate harvested in October. Tilvikiene et al. (2016) have reported that depending on nitrogen fertilization rate, tall fescue yields varied between 12 to 13.5 tons of DM per hectare, while reed canary grass from $8-10$ tons of DM per hectare. In our experiment, the highest biomass yield (6.99 tons of DM from hectare) of tall fescue was achieved in the treatment fertilized with mineral nitrogen and harvested in October. Reed canary grass showed better results also in mineral nitrogen fertilization treatment, but July was a more appropriate harvesting time when the yield reached a level of almost 8 tons of DM per hectare.

In each year of our study, the highest biomass yield in both grasses was achieved in the mineral nitrogen fertilization treatments (Fig. 1). In the first year of sward use, reed canary grass cut in July and fertilized with $\mathrm{N}_{90 \text { (mineral) }}$ accumulated $7.05 \mathrm{tha}^{-1}$ ofDM and when fertilized

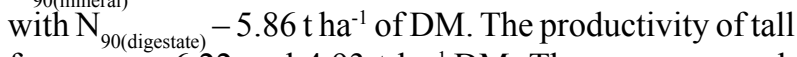
fescue was 6.22 and $4.93 \mathrm{t} \mathrm{ha}^{-1} \mathrm{DM}$. There was no such high difference in the swards harvested in October. Reed canary grass fertilized with $\mathrm{N}_{90 \text { (mineral) }}$ yielded $5.78 \mathrm{t} \mathrm{ha}^{-1}$ $\mathrm{DM}$ and fertilized with $\mathrm{N}_{90 \text { (digestate) }}-5.26 \mathrm{t} \mathrm{ha}^{-1} \mathrm{DM}$. The biomass yield of tall fescue was 5.82 and $6.02 \mathrm{t} \mathrm{ha}^{-1} \mathrm{DM}$, respectively. A similar trend was observed in the second year of sward use.

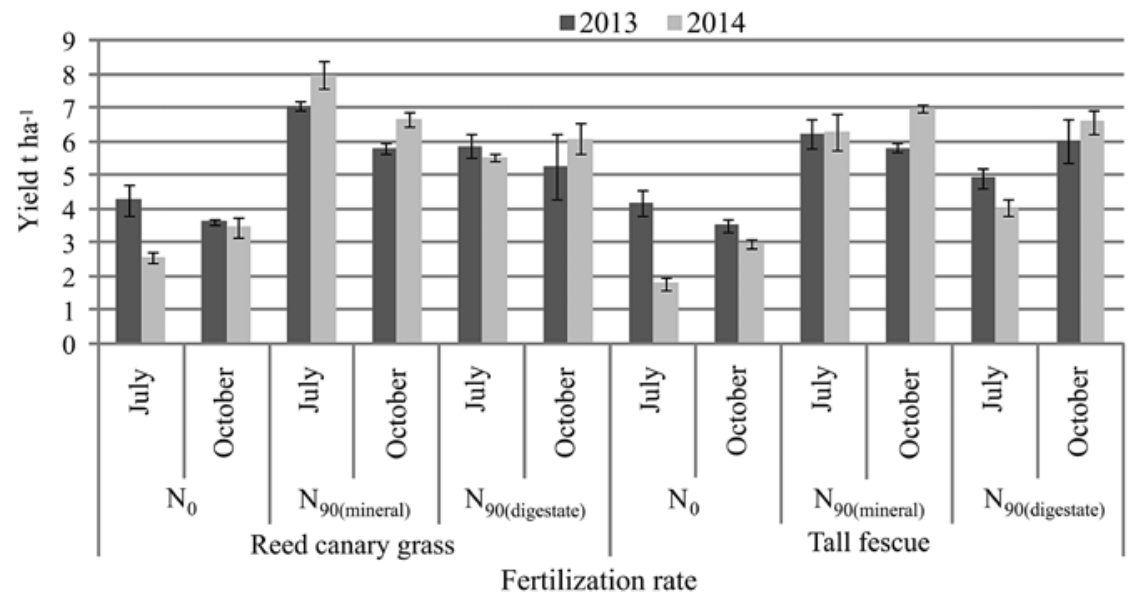

Notes. The vertical bars indicate the standard error of the mean values. $\mathrm{LSD}$ : $\mathrm{A}-\mathrm{ns}, \mathrm{B}-{ }^{* *}, \mathrm{C}-\mathrm{ns}, \mathrm{A} \times \mathrm{B}-\mathrm{ns}, \mathrm{A} \times \mathrm{C}-\mathrm{ns}, \mathrm{B} \times$ $\mathrm{C}-\mathrm{ns}, \mathrm{A} \times \mathrm{B} \times \mathrm{C}-\mathrm{ns}\left(1^{\text {st }}\right.$ year of sward use $)$, LSD: $\mathrm{A}-* *, \mathrm{~B}-* *, \mathrm{C}-* *, \mathrm{~A} \times \mathrm{B}-\mathrm{ns}, \mathrm{A} \times \mathrm{C}-* *, \mathrm{~B} \times \mathrm{C}-* *, \mathrm{~A} \times \mathrm{B} \times \mathrm{C}-*\left(2^{\text {nd }}\right.$ year of sward use); ${ }^{* *}$ - the least significant difference at $P<0.05$ and $P<0.01$, respectively; ns - not significant. A - grass species, $\mathrm{B}$ - fertilization rate, $\mathrm{C}$ - harvesting time.

Figure 1. Dry matter yield of reed canary grass and tall fescue as influenced by harvesting time

July harvesting was more suitable for reed canary grass fertilized with mineral nitrogen, while tall fescue gave better results in digestate fertilization treatment when harvested in October, which agrees with other authors' data suggesting that late harvesting is preferable for grasses (Cherney, Verma, 2013; Rancane et al., 2015). While according to Seppälä et al. (2009), the biomass yield of tall fescue could vary depending on harvesting time and it was highest when harvested July harvesting, which is contrary to our experimental data.

The analysis of fibre components in grass biomass. Biomass quality depends on the plant composition - cellulosic biomass is primarily comprised of cellulose, hemicellulose, lignin, and lesser amount of other extractable components (Tanger et al., 2013).
Fibre components of the studied reed canary grass and tall fescue are presented in Table 2. One of the most important biomass components for burning is lignin, because it contains a high content of carbon (Prochnow et al., 2009). In our research the concentration of lignin in the biomass of reed canary grass and tall fescue was significantly influenced by the grass species and timing of cuts. A significant influence of nitrogen application on lignin concentration was obtained only in the first year of sward use. A significant influence of the interaction between grass species and nitrogen fertilization on lignin concentration was obtained in the second year of sward use (Table 2).

According to Wrobel et al. (2008), with advancing maturity of reed canary grass the lignin and 
Table 2. The concentration of fibre components in reed canary grass and tall fescue biomass

\begin{tabular}{|c|c|c|c|c|c|c|c|}
\hline \multirow[t]{2}{*}{ Harvesting time } & \multirow{2}{*}{$\begin{array}{l}\text { Nitrogen } \\
\text { fertilization } \\
\mathrm{kg} \mathrm{ha}^{-1} \mathrm{~N}\end{array}$} & \multicolumn{2}{|c|}{$\begin{array}{c}\text { Hemicellulose } \\
\%\end{array}$} & \multicolumn{2}{|c|}{$\begin{array}{c}\text { Cellulose } \\
\%\end{array}$} & \multicolumn{2}{|c|}{$\begin{array}{c}\mathrm{ADL} \\
\%\end{array}$} \\
\hline & & 2013 & 2014 & 2013 & 2014 & 2013 & 2014 \\
\hline \multicolumn{8}{|c|}{ Reed canary grass } \\
\hline \multirow{3}{*}{ July } & $\mathrm{N}_{0}$ & 20.83 & 16.23 & 33.94 & 33.74 & 8.76 & 6.30 \\
\hline & $\mathrm{N}_{90 \text { (mineral) }}$ & 18.07 & 14.17 & 34.79 & 35.25 & 9.31 & 8.82 \\
\hline & $\mathrm{N}_{90 \text { (digestate) }}$ & 19.20 & 17.00 & 36.03 & 34.70 & 9.44 & 7.36 \\
\hline \multirow{3}{*}{ October } & $\mathrm{N}_{0}$ & 17.70 & 14.30 & 40.96 & 36.88 & 5.71 & 8.05 \\
\hline & $\mathrm{N}_{90 \text { (mineral) }}$ & 21.93 & 16.50 & 38.14 & 38.56 & 9.76 & 9.61 \\
\hline & $\mathrm{N}_{90 \text { (digestate) }}$ & 20.40 & 16.13 & 36.88 & 39.29 & 10.22 & 7.95 \\
\hline \multicolumn{8}{|c|}{ Tall fescue } \\
\hline \multirow[t]{2}{*}{ July } & $\mathrm{N}_{0}$ & 19.30 & 18.93 & 34.23 & 36.36 & 5.44 & 7.18 \\
\hline & $\mathrm{N}_{90 \text { (mineral) }}$ & 19.33 & 17.27 & 36.23 & 33.18 & 6.74 & 4.99 \\
\hline \multirow{4}{*}{ October } & $\mathrm{N}_{90 \text { (digestate) }}$ & 20.50 & 21.30 & 38.97 & 33.30 & 7.60 & 6.30 \\
\hline & $\mathrm{N}_{0}$ & 21.93 & 15.90 & 43.75 & 38.05 & 7.42 & 7.45 \\
\hline & $\mathrm{N}_{90 \text { (mineral) }}$ & 21.27 & 22.37 & 39.55 & 38.20 & 10.52 & 7.27 \\
\hline & $\mathrm{N}_{90 \text { (digestate) }}$ & 21.30 & 22.00 & 42.53 & 37.27 & 7.71 & 7.50 \\
\hline \multicolumn{8}{|c|}{ Actions and interactions: } \\
\hline \multicolumn{2}{|c|}{ A (grass species) } & ns & $* *$ & $*$ & ns & $*$ & $* *$ \\
\hline \multicolumn{2}{|c|}{ B (nitrogen fertilization) } & ns & ns & ns & $\mathrm{ns}$ & $* *$ & ns \\
\hline \multicolumn{2}{|c|}{$\mathrm{C}$ (timing of cuts) } & ns & ns & $* *$ & $* *$ & $*$ & $* *$ \\
\hline \multicolumn{2}{|c|}{$\mathrm{A} \times \mathrm{B}$} & ns & ns & ns & $\mathrm{ns}$ & ns & $* *$ \\
\hline \multicolumn{2}{|c|}{$\mathrm{A} \times \mathrm{C}$} & ns & $*$ & ns & ns & ns & ns \\
\hline \multicolumn{2}{|c|}{$\mathrm{B} \times \mathrm{C}$} & ns & $* *$ & $*$ & ns & ns & ns \\
\hline \multicolumn{2}{|c|}{$\mathrm{A} \times \mathrm{B} \times \mathrm{C}$} & ns & ns & ns & $\mathrm{ns}$ & ns & $\mathrm{ns}$ \\
\hline
\end{tabular}

Notes. ADL - acid detergent lignin. The numbers selected with different values have significant difference. $*$ and $* *$ - the least significant difference at $P<0.05$ and $P<0.01$, respectively; ns - not significant.

cellulose content in its biomass increased. The highest lignin content was achieved in 2013 in reed canary grass swards fertilized with $\mathrm{N}_{90 \text { (digestate) }}$ and tall fescue swards fertilized with $\mathrm{N}_{90 \text { (mineral) }}$ (Table 2). In 2014, tall fescue fertilized with $\mathrm{N}_{90 \text { (mineral) }}$ accumulated less lignin compared to that fertilized with $\mathrm{N}_{90 \text { (digestate) }}$ and not fertilized swards. The opposite tendency was obtained for reed canary grass where the lowest lignin concentration was obtained in not fertilized swards (July cut) and fertilized with $\mathrm{N}_{90 \text { (digestate) }}$ (October cut). In our research we found out that in all the cases (except reed canary grass non-fertilized sample in 2013) the highest concentrations of cellulose and lignin were identified in the biomass harvested in October and this was true not only for reed canary grass but also for tall fescue. In reed canary grass the differences were the lowest, but in all the cases, October harvesting gave the highest amount of lignin from $0.54-1.75 \%$ in both fertilization treatments. In the biomass of tall fescue harvested in October, ADL varied and was by 0.27 $2.23 \%$ higher in different treatments compared with July harvesting. Some authors came to the conclusion that the highest content of ADL or lignin in biomass could be reached with the application of extensive grassland management system with one late cut and low fertilization level (Rancane et al., 2015). In this research, the highest lignin and cellulose concentrations were achieved for October harvesting in both species which agrees with the data obtained by other authors. The relationship between biomass chemical composition and harvesting time was explained by Pahkala et al. (2007) who indicated that lignin and cellulose content in reed canary grass increased with advancing maturity.

Not only lignin but also cellulose and hemicellulose contents are important for solid biofuels. In both years of sward use timing of harvesting had a significant influence on both grasses. As for cellulose content in the biomass, the highest differences were determined in non-fertilized swards of both grasses. In mineral nitrogen fertilization treatment, tall fescue and reed canary grass reached a similar cellulose content when reed canary was harvested in July and tall fescue in October. In the digestate fertilization treatment, tall fescue achieved $3.56 \%$ higher cellulose concentration in the biomass harvested in October compared with July harvesting. The same trend was observed for the year 2014 - October harvesting gave the highest amount of cellulose in both grasses. In reed canary grass the results varied and were higher in comparison with in July-harvested biomass $3.14,3.31$ and 4.59 in nonfertilized, fertilized with mineral nitrogen and fertilized with digestate, for tall fescue the values were -1.69 , 5.02 and 3.97, respectively. In 2013, in non-fertilized samples of reed canary grass harvested in October the amount of cellulose was by $7.02 \%$ higher than in the samples harvested in July. Tall fescue in the same conditions gave $9.25 \%$ higher cellulose concentration in the biomass compared with July harvesting. Reed canary grass fertilized with mineral nitrogen and digestate 
and harvested in October gave $3.35 \%$ and $0.85 \%$ more cellulose in the biomass compared with July harvesting. The variation of cellulose, hemicellulose and lignin was most influenced by the time of harvesting (Kandel et al., 2013; Tilvikiene et al., 2016). The differences in the contents of these compounds in the plant biomass determine the originality of their characteristics and species diversity.

Hemicellulose content in biomass varied a lot and in the first year of sward use non fertilized samples of reed canary grass had higher amount of hemicellulose when harvested in July. In all other cases in reed canary grass and in tall fescue the highest concentration of hemicellulose was achieved in October harvested biomass. In the second year of sward use the situation remained the same - non-fertilized samples of reed canary grass had higher concentration of hemicellulose in July-harvested biomass. In all other swards the highest hemicellulose concentration for both grases was measured in October-harvested biomass. Significant differences were obtained because of the grass species and timing of cuts and their interaction in both years of sward use. Seasonal variation of herbage biomass also occurred and, commonly, the content of hemicellulose in the herbage biomass was higher in August than in
May (Elgersma, Søegaard, 2016). As a rule, with grass aging the quality of herbage tended to decline (Seppälä et al., 2009; Elgersma, Søegaard, 2016). However, the requirements for biomass properties for feed or anaerobic digestion are completely different from those intended for combustion. Typically, advancing maturity stage increases the concentration of fibre components (Kandel et al., 2013; Butkute et al., 2014) appropriate for feedstock intended for combustion.

Energy yield. Apart from biomass yield and quality, energy yield is a more general indicator of biomass suitability for combustion. Like biomass yield, energy yield was affected by fertilization and interaction between grass species and harvesting time in the first year of sward use. Both grasses produced the highest energy yield in the treatment fertilized with mineral nitrogen and harvested in July. The non-fertilized, July-harvested reed canary grass biomass yielded $80 \mathrm{GJ} \mathrm{ha}^{-1}$ in the first year of sward use and $46 \mathrm{GJ} \mathrm{ha}^{-1}$ in the second year of sward use. Fertilization with organic nitrogen (digestate) yielded 110 and $103 \mathrm{GJ}^{\mathrm{h}} \mathrm{h}^{-1}$, respectively. However, in the second year of sward use significant differences were found not only resulting from the effects of individual factors (grass species, fertilization and harvesting time) but also from their interaction (Fig. 2).

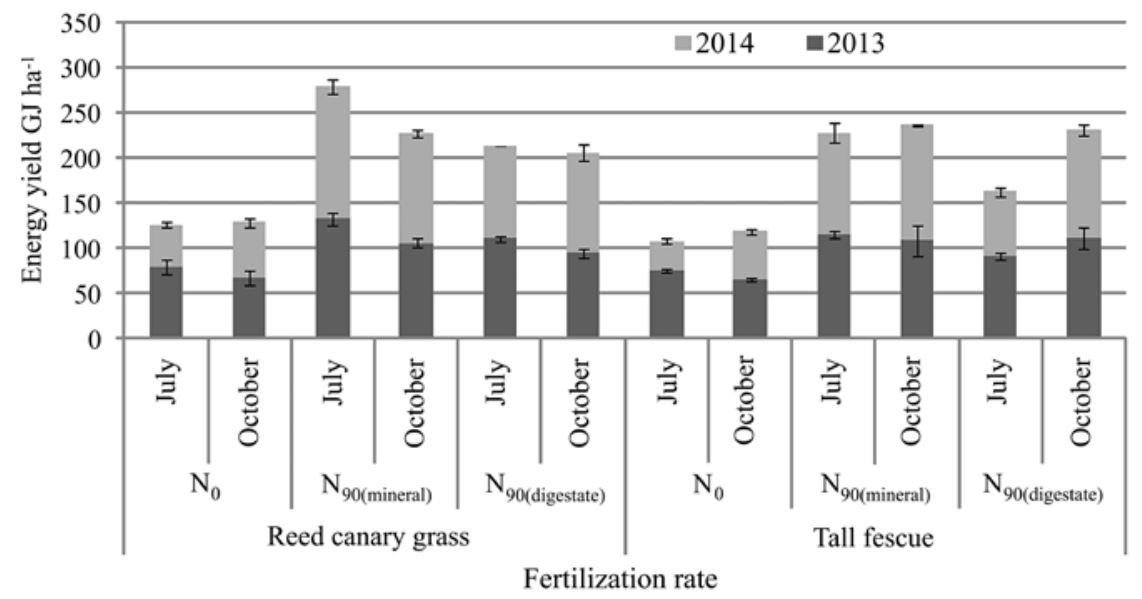

Notes. The vertical bars indicate the standard error of the mean values. $\mathrm{LSD}$ : $\mathrm{A}-\mathrm{ns}, \mathrm{B}-{ }^{* *}, \mathrm{C}-\mathrm{ns}, \mathrm{A} \times \mathrm{B}-\mathrm{ns}, \mathrm{A} \times \mathrm{C}-{ }^{*}, \mathrm{~B} \times$ $\mathrm{C}-\mathrm{ns}, \mathrm{A} \times \mathrm{B} \times \mathrm{C}-\mathrm{ns}\left(1^{\mathrm{st}}\right.$ year of sward use $)$, LSD: $\mathrm{A}-* *, \mathrm{~B}-* *, \mathrm{C}-* *, \mathrm{~A} \times \mathrm{B}-\mathrm{ns}, \mathrm{A} \times \mathrm{C}-* *, \mathrm{~B} \times \mathrm{C}-* *, \mathrm{~A} \times \mathrm{B} \times \mathrm{C}-*\left(2^{\text {nd }}\right.$ year of sward use); $* *$ - the least significant difference at $P<0.05$ and $P<0.01$, respectively; ns - not significant. A - grass species, $\mathrm{B}$ - fertilization rate, $\mathrm{C}$ - harvesting time.

Figure 2. Energy yield in two years of sward use in reed canary grass and tall fescue

However, the energy yield of non-fertilized, October-harvested samples of reed canary grass in the first year of sward use was $67 \mathrm{GJ}^{-1} \mathrm{ha}^{-1}$, i.e. lower than that of July-harvested sward, and in the second year of sward use it was $61 \mathrm{GJ} \mathrm{ha}^{-1}$, i.e. higher than that of Julyharvested sward in 2014. The energy yield of mineral nitrogen-applied treatment in 2013 and 2014 amounted to 106 and $122 \mathrm{GJ} \mathrm{ha}^{-1}$, respectively. Fertilization with digestate gave an energy yield of $95 \mathrm{GJ} \mathrm{ha}^{-1}$ in the first year of sward use and $111 \mathrm{GJ} \mathrm{ha}^{-1}$ in the second year. Tall fescue showed better results: the October-harvested nonfertilized swards yielded 65 and $53 \mathrm{GJ} \mathrm{ha}^{-1}$, respectively. In mineral nitrogen fertilization treatment, energy yield was higher and reached $108 \mathrm{GJ}^{\text {ha }}{ }^{-1}$ in 2013 and $128 \mathrm{GJ} \mathrm{ha}^{-1}$ in 2014. Digestate application exerted a positive effect and energy yield amounted to $112 \mathrm{GJ} \mathrm{ha}^{-1}$ in first year of sward use and $119 \mathrm{GJ} \mathrm{ha}^{-1}$ in second year.

To conclude, energy yield depended on all factors studied in the second year of sward use. Fertilized swards gave the highest amount of energy per hectare compared with non-fertilized ones and grass species was a significant factor too. July harvesting was more suitable for reed canary grass since its biomass yielded the highest energy yield, while tall fescue swards showed the highest 
energy yields when harvested in October. Energy yield could also be influenced by the time of sward harvesting (Tonn et al., 2010).

It is generally accepted that biomass feedstocks with high levels of lignin are of higher calorific value (Demirbas, 2001), which means that they have greater energy potential. Of both species tested, only reed canary grass showed a significant correlation between ADL concentration in the biomass and energy yield (Fig. 3). As it could be seen from the data, higher ADL content resulted in increased energy yield. This is in line with other authors' data suggesting that high ADL content is preferable in the biomass for combustion (Rancane et al., 2015).

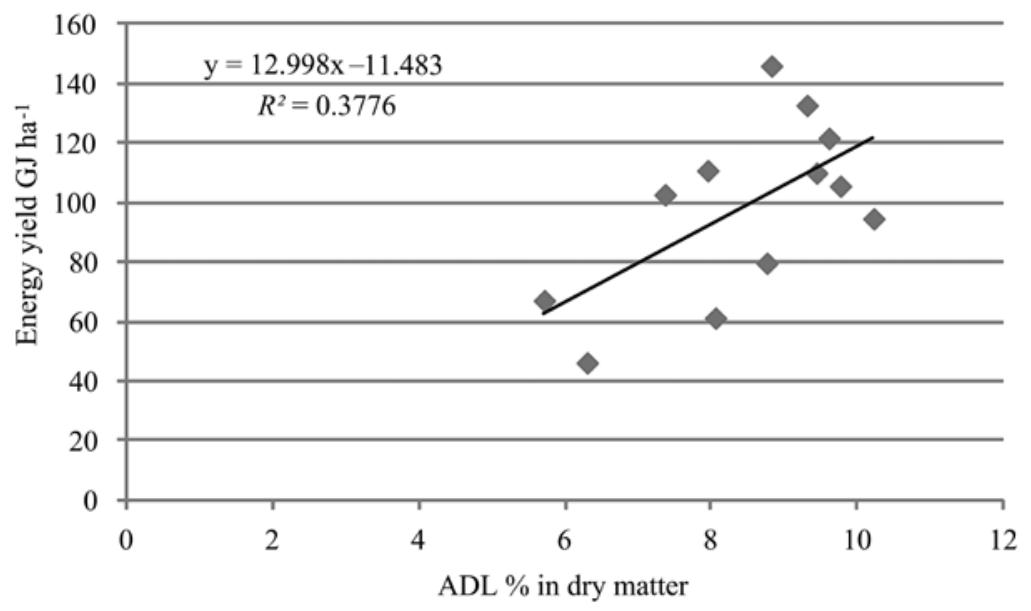

Figure 3. The correlation between energy yield and acid detergent lignin (ADL) content in reed canary grass in two years of use

\section{Conclusion}

1. The grass species and nitrogen fertilization significantly affected biomass yield of both grasses. The highest dry matter yield of $7.96 \mathrm{t} \mathrm{ha}^{-1}$ was produced by reed canary grass fertilized with mineral nitrogen and harvested in July. Tall fescue gave the highest biomass yield (6.99 $\mathrm{t}$ of DM per hectare) in the mineral nitrogen fertilization treatment too; however, October proved to be a more suitable harvesting time for this species.

2. Grass species and harvesting time had a significant effect on fibre components. The highest concentrations of acid detergent lignin (ADL) and cellulose were identified in the biomass of both grasses fertilized with nitrogen and harvested in October.

3. The influence of grass species and management factors on energy yield was observed. The highest energy yield, for reed canary grass was obtained in mineral nitrogen-fertilized and July-harvested treatment. For tall fescue the highest energy yield was only in October-harvested fertilized swards. A significant correlation between the ADL concentration in the biomass and energy yield of reed canary grass was established. Higher concentration of ADL was found to lead to higher energy yield.

Received 27042016

Accepted 27072016

\section{References}

Allen B., Kretschmer B., Baldock D., Menadue H., Nanni S., Tucker G. 2014. Space for energy crops - assessing the potential contribution to Europe's energy future. Report produced for BirdLife Europe, European Environmental Bureau and Transport and Environment. Institute European Environmental Policy, London, $63 \mathrm{p}$.

Butkute B., Lemeziene N., Kanapeckas J., Navickas K., Dabkevicius Z., Venslauskas K. 2014. Cocksfoot, tall fescue and reed canary grass dry matter yield, chemical composition and biomass convertibility to methane. Biomass and Bioenergy, 66: 1-11

http://dx.doi.org/10.1016/j.biombioe.2014.03.014

Cherney H. J., Verma K. V. 2013. Grass pellet quality index: a tool to evaluate suitability of grass pellets for small scale combustion systems. Applied Energy, 103: 679-684 http://dx.doi.org/10.1016/j.apenergy.2012.10.050

Demirbas A. 2001. Relationships between lignin contents and heating values of biomass. Energy Conversion and Management, 42: 183-188 http://dx.doi.org/10.1016/S0196-8904(00)00050-9

Doherty A., Walsh E., McDonnell K. 2012. The direct use of post-processing wood dust in gas turbines. Journal of Sustainable Bioenergy Systems, 2: 60-64 http://dx.doi.org/10.4236/jsbs.2012.23009

Elgersma A., Søegaard K. 2016. Effects of species diversity on seasonal variation in herbage yield and nutritive value of seven binary grass-legume mixtures and pure grass under cutting. European Journal of Agronomy, 78: 73-83 http://dx.doi.org/10.1016/j.eja.2016.04.011

Han M., Kang K. E., Kim V., Choi G. W. 2013. High efficiency bioethanol production from barley straw using a continuous pretreatment reactor. Process Biochemistry, 48 (3): 488-495

http://dx.doi.org/10.1016/j.procbio.2013.01.007 
Healion K. 2002. Wood as a renewable source of energy. COFORD Connects, Socio-Economic Aspects of Forestry, No. 1

Heinsoo K., Hein K., Melts I., Holm B., Ivask M. 2011. Reed canary grass yield and fuel quality in Estonian farmers' fields. Biomass and Bioenergy, 35: 617-625 http://dx.doi.org/10.1016/j.biombioe.2010.10.022

Jasinskas A. Zaltauskas A., Kryzeviciene A. 2008. The investigation of growing and using of tall perennial grasses as energy crops. Biomass and Bioenergy, 32: 981-987 http://dx.doi.org/10.1016/j.biombioe.2008.01.025

Kallioinen A., Uusitalo J., Pahkala K., Kontturi M., Viikari L., von Weymarn N., Siika-aho M. 2012. Reed canary grass as a feedstock for $2^{\text {nd }}$ generation bioethanol production. Bioresource Technology, 123: 669-672 http://dx.doi.org/10.1016/j.biortech.2012.07.023

Kandel T. P., Sutaryo S., Møller H. B., Jørgensen U., Lærke P. E. 2013. Chemical composition and methane yield of reed canary grass as influenced by harvesting time and harvest frequency. Bioresource Technology, 130: 659-666 http://dx.doi.org/10.1016/j.biortech.2012.11.138

Kołodziej B., Stachyra M., Antonkiewicz J., Bielińska E., Wiśniewski J. 2016. The effect of harvest frequency on yielding and quality of energy raw material of reed canary grass grown on municipal sewage sludge. Biomass and Bioenergy, 85: 363-370 http://dx.doi.org/10.1016/j.biombioe.2015.12.025

Lemežienė N., Butkutė B., Kanapeckas J., Dabkevičienė G., Kadžiulienė Ž., Kemešyte V., Stukonis V., Vilčinskas E. 2011. Screening of the accessions of tall perennial grass species as feasible energy crops for biomethane production. Journal of Food and Environment, 9: 941-946

Lewandowski I., Scurlock J. M. O., Lindvall E., Christou M. 2003. The development and current status of perennial rhizomatous grasses as energy crops in the US and Europe. Biomass and Bioenergy, 25: 335-361 http://dx.doi.org/10.1016/S0961-9534(03)00030-8

Lord R. A. 2015. Reed canary grass (Phalaris arundinacea) outperforms Miscanthus or willow on marginal soils, brownfield and non-agricultural sites for local, sustainable energy crop production. Biomass and Bioenergy, 78: $110-125$ http://dx.doi.org/10.1016/j.biombioe.2015.04.015

Nilsson D., Rosenqvist H., Bernesson S. 2015. Profitability of the production of energy grasses on marginal agricultural land in Sweden. Biomass and Bioenergy, 83: 159-168 http://dx.doi.org/10.1016/j.biombioe.2015.09.007

Pahkala K., Kontturi M., Kallioinen A., Myllymaki O., Uusitalo J., Siika-aho M., von Weymarn N. 2007. Production of bio-ethanol from barley straw and reed canary grass: a raw material study. $15^{\text {th }}$ European biomass conference and exhibition. Berlin, Germany, p. 154-157

Panoutsou C., Elbersen B., Böttcher H. 2011. Energy crops in the European context. Biomass Futures $<\mathrm{http}$ ://www. biomassfutures.eu/public_docs/final_deliverables/ WP 8/D 8.4\%20Energy\%20crops\%20in\%20the \%20 European \%20context\%20(contribution \%20to\%20 FNR\%20workshop).pdf>

Prochnow A., Heiermann M., Plöchl M., Amon T., Hobbs P. J. 2009. Bioenergy from permanent grassland - a review. 2 . Combustion. Bioresource Technology, 100: 4945-4954 http://dx.doi.org/10.1016/j.biortech.2009.05.069
Rancane S., Karklins A., Lazdina D., Berzins P., Bardule A., Butlers A., Lazdins A. 2015. The evaluation of biomass yield and quality of Phalaris arundinacea and Festulolium fertilised with bio-energy waste products. $14^{\text {th }}$ international scientific conference Engineering for Rural Development 2015. Jelgava, Latvia, p. 546-551

Rinne M., Jaakkola S., Huhtanen P. 1997. Grass maturity effects on cattle fed silage-based diets. 1. Organic matter digestion, rumen fermentation and nitrogen utilization. Animal Feed Science Technology, 67: 1-17 http://dx.doi.org/10.1016/S0377-8401(96)01141-8

Robbins M. P., Evans G., Valentine J., Donnison I. S., Allison G. G. 2012. New opportunities for the exploitation of energy crops by thermochemical conversion in Northern Europe and the UK. Progress Energy and Combustion Science, 38: 138-155 http://dx.doi.org/10.1016/j.pecs.2011.08.001

Seppälä M., Paavola T., Lehtomäki A., Rintala J. 2009. Biogas production from boreal herbaceous grasses. Specific methane yield and methane yield per hectare. Bioresource Technology, 100: 2952-2958 http://dx.doi.org/10.1016/j.biortech.2009.01.044

Tanger P., Field J. L., Jahn C. E., DeFoort M. W., Leach J. E. 2013. Biomass for thermochemical conversion: targets and challenges. Front Plant Science, 4: 1-20 http://dx.doi.org/10.3389/fpls.2013.00218

Tilvikiene V., Kadziuliene Z., Dabkevicius Z., Venslauskas K., Navickas K. 2016. Feasibility of tall fescue, cocksfoot and reed canary grass for anaerobic digestion: Analysis of productivity and energy potential. Industrial Crops and Products, 84: 87-96 http://dx.doi.org/10.1016/j.indcrop.2016.01.033

Tonn B., Thumm U., Claupein W. 2010 Semi-natural grassland biomass for combustion: influence of botanical composition, harvest date and site conditions on fuel composition. Grass and Forage Science, 65: 383-397 http://dx.doi.org/10.1111/j.1365-2494.2010.00758.x

Vassilev S. V., Baxter D., Andersen L. K., Vassileva C. G. 2013. An overview of the composition and application of biomass ash. Part 1. Phase-mineral and chemical composition and classification. Fuel, 105: 40-76 http://dx.doi.org/10.1016/j.fuel.2012.09.041

Wrobel C., Coulman B. E., Smith D. L. 2008. The potential use of reed canary grass (Phalaris arundinacea L.) as a biofuel crop. Acta Agriculturae Scandinavica, section B: Soil and Plant Science, 59: 1-18 
ISSN 1392-3196 / e-ISSN 2335-8947

Zemdirbyste-Agriculture, vol. 103, No. 3 (2016), p. 297-304

DOI 10.13080/z-a.2016.103.038

\title{
Nendrinių dryžučių ir nendrinių eraičinų, auginamų kaip žaliava deginti, biomasės derlius ir ląstelienos komponentai
}

\author{
L. Pocienè, Ž. Kadžiulienè
}

Lietuvos agrarinių ir miškų mokslų centro Žemdirbystès institutas

\section{Santrauka}

Daugiamečių žolių biomasė yra potenciali kietojo kuro (deginimo) žaliava. Eksperimentas ịrengtas giliau karbonatingame sekliai gejjiškame rudžemyje (RDg8-k2). Jo metu vertintas dviejų daugiamečių žolių biomasės derlius, kokybė ir energinis derlius. Deginti skirtos biomasės vertinimui pasirinktos dviejų rūšių daugiametės žolès - nendrinis eraičinas (Festuca arundinacea Schreb.) ir nendrinis dryžutis (Phalaris arundinacea L.). Pasirinktos dvi skirtingos trašos su vienodu kiekiu $\left(90 \mathrm{~kg} \mathrm{ha}^{-1}\right)$ azoto - tai mineralinès azoto trąšos ir biodujų gamybos atlieka (digestatas). Taip pat eksperimento metu įvertinta skirtingo pjūčių laiko įtaka biomasès derliui ir energiniam produktyvumui; pjūčių laikas pasirinktas vasarą (liepos mėnesį) ir rudens viduryje (spalio mènesị). Dvejų metų eksperimento duomenys atskleide, kad biomasès derlius ir energinis potencialas priklauso nuo žolių rūšies ir auginimo technologijų. Lyginant tos pačios žolių rūšies vienos pjūties rodiklius, didesni biomasès ir energinis derliai gauti nendrinius dryžučius pjaunant liepos mėnesį, o nendriniams eraičinams palankesnè rudeninė pjūtis spalio mėnesį. Abiejų rūšių žolynai buvo produktyviausi tręšiant mineraliniu azotu. Nendrinių dryžučių žolynų biomasès ir energinis derliai buvo didžiausi ir didesni už liepos pjūties nendrinių eraičinų biomasę. Žolynų energinị derlių didino didesnis kiekis lignino žolių biomasèje.

Reikšminiai žodžiai: biomasė deginimui, pjūčių laikas, tręšimas azotu, žolių rūšis.

Please use the following format when citing the article:

Pocienė L., Kadžiuliené Ž. Biomass yield and fibre components in reed canary grass and tall fescue grown as feedstock for combustion. Zemdirbyste-Agriculture, 103 (3): 297-304 DOI 10.13080/z-a.2016.103.038 